\title{
MARGA ENGRAULIDAE (FISHES) DI TELUK AMBON: DIVERSITAS, STRUKTUR UKURAN, DAN FAKTOR KONDISI
}

\author{
Augy Syahailatua*)
}

\begin{abstract}
ABSTRAK
Ikan pelagis kecil yang berlimpah di Teluk Ambon meliputi ikan-ikan dari marga Engraulidae. Ikan Engraulidae dikenal sebagai ikan umpan dalam perikanan cakalang, di samping itu masyarakat juga menjadikannya sebagai ikan konsumsi. Pengamatan berkala ikan Engraulidae di Teluk Ambon dilakukan 1995 sampai dengan 1998 dan 2004. Ada 7 jenis ikan yang termasuk marga ini, yaitu Encrasicholina heteroloba, E. punctifer, Engraulis japonicus S. indicus, Stolephorus sp., Thryssa baelama, dan $T$. setirostris. Dari analisis struktur panjang total $(\mathrm{cm})$, jumlah individu yang belum pernah memijah pada $E$. encrasicholina $(\leq 7,0 \mathrm{~cm})$ mencapai $75 \%$, dan pada $S$. indicus $(<14 \mathrm{~cm})$ mencapai $90 \%$. Faktor kondisi menunjukkan adanya variasi yang sama selama periode penelitian, yang mengindikasikan bahwa pengaruh faktor lingkungan dan musim selalu sama terhadap aspek biologi ikan Engraulidae (seperti pertumbuhan dan reproduksi). Pengurangan aktivitas penangkapan atau penutupan musim penangkapan mungkin harus dikaji untuk melestarikan sumber daya ini.
\end{abstract}

\section{ABSTRACT: Family of Engraulidae (fishes) in Ambon Bay: Diversity, size structure, and condition} factor. By: Augy Syahailatua

Small pelagic fishes are caught abundantly in Ambon Bay including fishes of Engarulidae. This family is well known as a baitfish in skipjack tuna fishery. In addition, people also use them as consumable fishes. Serial observation on the Engraulids in Ambon Bay was taken 1995-1998 and 2004. There are 7 species found during the study such as Encrasicholina heteroloba, E. punctifer, Engraulis japonicus S. indicus, Stolephorus sp., Tryssa baelama, and T. setirostris. Infomation on size structure shows that numbers of fishes caught in size less than the length at the first spawning $(\leq 7 \mathrm{~cm})$ for $\boldsymbol{E}$. heteroloba was $75 \%$ and for $\boldsymbol{S}$. indicus $(<14 \mathrm{~cm})$ was $90 \%$. Condition factors indicate a quite similar impact of oceanographic and seasonal characteristics on biological aspects (e.g.growth and reproduction). Decreasing of fishing activity or closing season for fishing may be introduced to protect the resources of engraulids in the bay.

KEYWORDS: $\quad$ engraulidae, diversity, size structure, condition factor, Ambon Bay

\section{PENDAHULUAN}

Ikan-ikan marga Engraulidae (selanjutnya disebut ikan Engraulidae) tergolong dalam kelompok ikan pelagis kecil, yang hidupnya bergerombol di daerah pantai atau pesisir. Daerah penyebarannya sangat luas meliputi Samudera Atlantik, Hindia, dan Pasifik (Froese \& Pauly 2005). Genus dari marga Engraulidae yang ditemukan di perairan Indonesia adalah Coilia (6 jenis), Encrasicholina (3), Engraulis (1), Papuengraulis (1), Setipinna (3), Stolephorus (9), dan Tryssa (7) (Hutomo et al., 1987; Froese \& Pauly, 2005). Dalam kegiatan penangkapan ikan, kelompok ikan Engraulidae sangat berguna sebagai ikan umpan, terutama perikanan cakalang (Sumadhiharga, 1978, 1984; Hutomo et al., 1987). Dengan demikian, keberadaan ikan Engarulidae akan sangat menentukan keberhasilan penangkapan ikan pelagis besar, seperti cakalang.

Di perairan Teluk Ambon, ikan Engraulidae merupakan salah satu hasil tangkapan utama nelayan yang mengoperasikan bagan apung atau jaring pantai (Sumadhiharga, 1978, 1984, 1989; Wouthyuzen et al. 1984; Sumadhiharga \& Yulianto, 1987; Syahailatua 1998, 1999). Selain dipergunakan sebagai ikan umpan, kelompok ikan ini juga dikonsumsi oleh masyarakat (Hutomo et al., 1987). Pengkajian tentang aspek biologi ikan Engraulidae di Teluk Ambon sudah dilakukan sejak awal tahun 1970-an (Sumadhiharga, 1978, 1984, 1989; Wouthuyzen et al., 1984; Sumadhiharga \& Yulianto, 1987; Pattikawa \& Ongkers, 2003), dengan tujuan supaya kelestarian ikan-ikan ini tetap terjamin. Sejalan dengan perubahan lingkungan Teluk Ambon akibat pertambahan penduduk, pembukaan lahan baru, dan industri maritim, maka secara perlahan sejak awal tahun 1980-an, ikan-ikan marga ini mulai menurun dalam hasil tangkapan nelayan.

Tahun 1995 sampai dengan 1998 dan 2004 dilakukan pemantauan ikan-ikan hasil tangkapan jaring pantai di Teluk Ambon, khususnya di bagian dalam teluk, dan hasil penelitian menunjukkan bahwa ikan Engraulidae termasuk ikan yang dominan (Syahailatua 1998; 1999). Dengan demikian, kajian dalam tulisan ini akan mengungkapan beberapa aspek biologi dari ikan Engraulidae di Teluk Ambon seperti biodiversitas, variasi dalam kelimpahan, struktur ukuran panjang dan faktor kondisi. Informasi yang diperoleh dari penelitian ini diharapkan dapat menjelaskan status ikan Engarulidae dalam 10 tahun terakhir di Teluk Ambon.

\footnotetext{
Pusat Penelitian Oseanografi, Lembaga IImu Pengetahuan Indonesia, Jakarta
} 


\section{BAHAN DAN METODE}

\section{Lokasi dan Waktu Pengumpulan Contoh}

Pengamatan ikan Engraulidae dilakukan di Teluk Ambon bagian dalam yang merupakan bagian dari Teluk Ambon (Pulau Ambon, Gambar 1). Deskripsi lengkap tentang kondisi geomorfologi dan oseanografi Teluk Ambon bagian dalam dapat diperoleh dari beberapa hasil penelitian terdahulu (Troost et al., 1976; Anderson \& Sapulete, 1981; Sutomo \& Anderson, 1984; Wenno \& Anderson, 1984; Wenno, 1979; 1986; 1997; Hermanto, 1987; Walman \& Anderson, 1987; Tarigan \& Sapulete, 1987; Hutahaean, 1996; Wouthuyzen, 2001). Pengumpulan contoh ikan dilakukan selama tahun 1995 sampai dengan 1998, kemudian dilanjutkan kembali tahun 2004.

\section{Pengumpulan dan Perlakukan Contoh}

Koleksi contoh ikan dilakukan dengan jaring pantai (nama lokal Redi) yang dioperasikan oleh nelayan lokal di Desa Lateri Teluk Ambon bagian dalam. Contoh ikan dikumpulkan setiap 2 minggu selama periode penelitian. Contoh diambil pada saat jaring didaratkan ke pantai dan dilakukan secara acak dari hasil tangkapan jaring tersebut. Kisaran bobot seluruh contoh antara 0,5 sampai dengan $7,0 \mathrm{~kg}$, sedangkan bobot maksimum contoh ikan Engraulidae mencapai 2 kg. Seluruh contoh kemudian dianalisis lebih detail di Laboratorium Biologi Perikanan, Lembaga IImu Pengetahuan Indonesia (sekarang: Unit Pelaksana Teknis Balai Konservasi Biota Laut).

Semua contoh ikan disortir dan diidentifikasi pada tingkatan jenis dengan menggunakan beberapa kunci identifikasi ikan, sedangkan khusus untuk ikan Engaulidae diidentifikasi menurut Whitehead (1985). Jumlah individu per jenis dihitung, selanjutnya setiap individu diukur panjang total $(\mathrm{cm})$ dan ditimbang bobot basahnya $(\mathrm{g})$. Pemeriksaan jenis kelamin dan tingkat kematangan gonada juga dilakukan dengan membedah bagian perut dari ikan-ikan contoh tersebut. Pengamatan ini hanya dilakukan untuk membantu menduga musim pemijahan, namun datanya tidak dianalisis.

\section{Analisis Data}

Hasil analisis beberapa parameter biologi disederhanakan dengan hanya menampilkan nilai

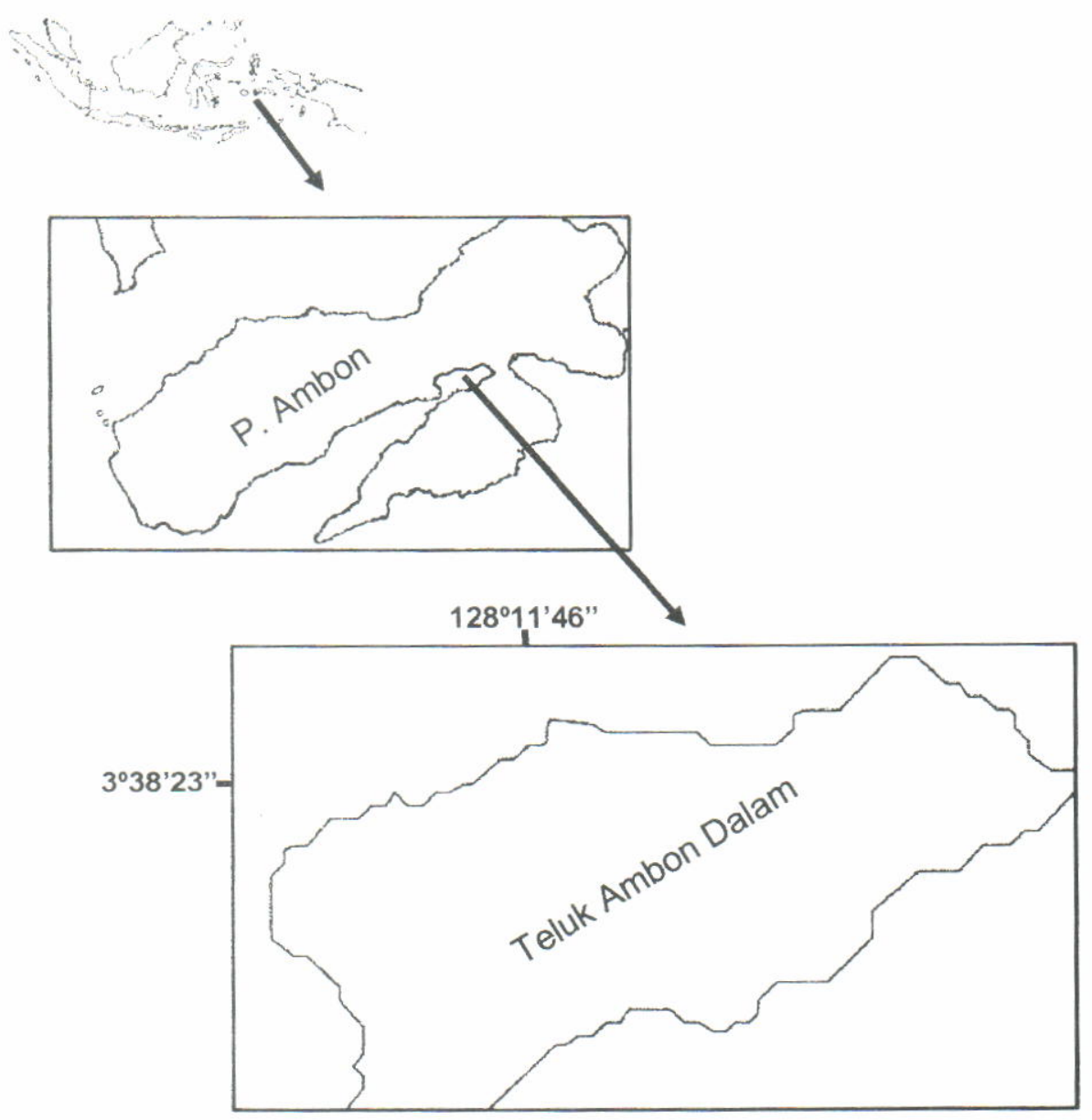

Gambar 1. Lokasi pengamatan ikan Engaulidae di Teluk Ambon, 1995 sampai dengan 1998 dan 2004. Figure 1. Location of Engaulids sampling in Ambon Bay, 1995-1998 and 2004. 
rata-rata dan simpangan baku pada beberapa grafik dan tabel. Variasi kehadiran kelompok ikan Engraulidae dalam keseluruhan hasil tangkapan digambarkan dalam persentase jumlah individu. Di samping itu, frekuensi panjang ikan (\%) ditampilkan dalam grafik distribusi panjang total setiap individu, dan dikelompokkan menurut tahun penelitian, kemudian dilakukan uji dengan the KolmogorovSmirnov test (K-S). Selanjutnya, faktor kondisi dikaj untuk 3 jenis Engraulidae dengan menggunakan rumus regresi panjang-bobot yaitu

$$
W=a \cdot L^{b}
$$

atau dapat ditransformasikan ke dalam bentuk logaritma, yaitu:

$\log W=\log a+b \log L$

di mana

$W=$ Bobot individu dalam gram

$\mathrm{L}$ = Panjang total dalam $\mathrm{cm}$

a $=$ Nilai intersep

$\mathrm{b}=$ Nilai kemiringan garis regresi

Grafik regresi panjang bobot hanya digambarkan bagi $E$. heteroloba, $S$. indicus, dan $T$. baelama untuk melihat variasi tahunan. Berdasarkan pada persamaan ini, diperoleh nilai bobot dugaan individu ikan (W'), dan selanjutnya, nilai $W$ dibandingkan dengan nilai bobot ikan sebenarnya (W), sehingga dihasilkan Faktor Kondisi Relative ( $\mathrm{Kn}$ ), yang dapat ditulis sebagai $K n=W W^{\prime}$ (Cone, 1989). Nilai faktor kondisi ini kemudian diperbandingan antara bulan untuk 3 jenis tersebut di atas

Analisis sidik ragam (ANOVA) untuk melihat variasi kehadiran jenis Engraulidae setiap bulan, perbedaan frekuensi panjang total setiap tahun, tendensi perubahan regresi panjang bobot dan faktor kondisi. Transformasi data dilakukan sekiranya data dikategorikan tidak menyebar merata sesuai dengan kaidah Cochran (Sokal \& Rohlf, 1969; Steel \& Torrie, 1993)

\section{HASIL DAN BAHASAN}

\section{Komposisi Jenis dan Kelimpahan}

Selama periode penelitian ini, jumlah contoh ikan Engraulidae yang terkumpul 6.832 individu dengan bobot $18.349,1 \mathrm{~g}$ atau $33,3 \%$ (individu) dan $16,4 \%$ (bobot) dari total jumlah contoh ikan (20.528 individu dengan bobot 112.272,2 g). Komposisi ikan Engraulidae yang dikumpulkan terdiri atas 7 jenis $(6$ dapat diidentifikasi pada tingkatan spesies dan 1 pada tingkatan genus, Tabel 1). Jenis yang sangat dominan menurut jumlah individu adalah $E$. heteroloba, $S$. indicus, $E$. punctifer, dan $T$ baelama. Namun ke-4 jenis ini mengalami variasi dalam frekuensi kehadirannya (Tabel 1), yaitu $E$. heteroloba dan $S$. indicus memiliki frekuensi kehadiran yang tingg masing-masing 65 dan $60 \%$, disusul oleh $T$. baelama dengan $37 \%$, sedangkan E. punctifer hanya $7 \%$. Ke-5 jenis lain memiliki persentase jumlah individu kurang dari $1 \%$ dan frekuensi kehadiran yang kurang dari $5 \%$, kecuali $T$. setirostris yang frekuensi kehadirannya $16 \%$ (lebih tinggi dari E. punctifer). Dengan demikian, terdapat sedikit variasi dalam jumlah individu dan frekuensi kehadiran, yaitu tidak semua jenis yang memiliki banyak individu juga memiliki frekuensi kehadiran yang tinggi, sebagai contoh $E$. punctifer dan $T$. setirostris

Variasi dalam jumlah individu, robot, dan frekuensi kehadirannya juga terlihat dalam hasil ANOVA (Tabel 2 dan Gambar 2) terhadap periode bulan (Januari sampai dengan Desember) yang menunjukkan bahwa tidak terdapat perbedaan yang nyata berdasarkan pada jumlah individu dan jumlah bobot dari ikan Engraulidae di Teluk Ambon selama penelitian. Ini berarti, kehadiran ikan Engraulidae dianggap tidak berfluktuasi sepanjang tahun menurut jumlah jenis dan individu.

\section{Distribusi Panjang}

Variasi panjang total ikan-ikan Engraulidae antara 3 sampai dengan $15 \mathrm{~cm}$, namun setiap jenis mempunyai tendensi pengelompokkan ukuran panjang yang berbeda (Tabel 3). Hasil pengukuran panjang dari 4 jenis ikan ditampilkan dalam grafik distribusi (Gambar 3) dengan seri data yang berbeda, yaitu 2 jenis ( $E$. heteroloba dan $S$. indicus) memiliki data tahun 1995 sampai dengan 1998 dan 2004, 1 jenis ( $T$. baelama) dari data tahun 1995 sampai dengan 1998, sedangkan 1 jenis (E. puntifer) hanya diperoleh data tahun 1995 dan 1996.

Uji K-S dipergunakan untuk membuktikan perbedaan frekuensi panjang antar periode bulan dan tahun (Tabel 4 dan 5), dan rata-rata panjang total per bulan disajikan dalam Gambar 4. Hasilnya menunjukkan bahwa secara umum terdapat variasi dalam ukuran panjang pada ke-4 jenis Engarulidae menurut periode bulan ataupun tahunan. Di samping itu, E. heteroloba yang tertangkap hampir $75 \%$ berada di bawah ukuran pertama kali matang gonad $(\leq 7 \mathrm{~cm}$ PT), sedangkan bagi $S$. indicus lebih dari $10 \%$ yang berada pada ukuran dewasa (>14 cm PT). Ini berarti, ikan Engraulidae yang tertangkap di Teluk Ambon selama 10 tahun terakhir memiliki variasi ukuran menurut periode bulan dan tahun, dan juga banyak tertangkap dalam ukuran yang belum dewasa.

\section{Faktor Kondisi (Kn)}

Hasil perhitungan $\mathrm{Kn}$ diperoleh lewat analisis regresi panjang bobot. Awalnya analisis regresi panjang bobot untuk 3 jenis yang domian dibuat terpisah untuk setiap tahun (Tabel 3, Gambar 5), 


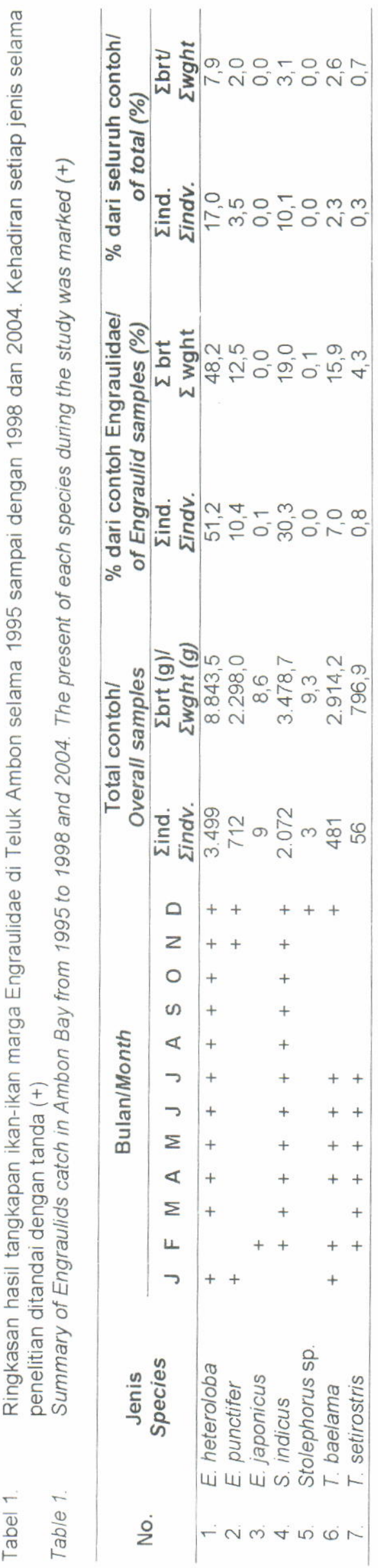


Tabel 2 .

Hasil ANOVA terhadap variasi jumlah individu dan bobot ikan-ikan Engralidae sepanjang tahun, bulan Januari sampai dengan Desember di Teluk Ambon

Table 2. ANOVA results on monthly variation of total individual and weight of Engraulids in Ambon Bay

\begin{tabular}{|c|c|c|c|c|c|}
\hline $\begin{array}{l}\text { Sumber } \\
\text { source }\end{array}$ & $\begin{array}{l}\text { JK } \\
\text { SS }\end{array}$ & $\begin{array}{l}\text { DB } \\
\text { DF }\end{array}$ & $\begin{array}{l}\mathrm{KT} \\
\mathrm{MS}\end{array}$ & $\begin{array}{c}\text { F-hitung } \\
\text { F-value }\end{array}$ & $\begin{array}{l}\text { Nilai -P } \\
P \text {-value }\end{array}$ \\
\hline \multicolumn{6}{|c|}{ a. Menurut jumlah individu/Total number of individual } \\
\hline $\begin{array}{l}\text { Antar bulan } \\
\text { Among months }\end{array}$ & $7.041,37$ & 11 & 640,12 & 0,85 & $0,60 \mathrm{NS}$ \\
\hline $\begin{array}{l}\text { Residu } \\
\text { Residual }\end{array}$ & $18.071,02$ & 24 & 752,96 & & \\
\hline Total & $25.112,39$ & 35 & & & \\
\hline \multicolumn{6}{|c|}{ b. Menurut bobot individu/Total weight of individual } \\
\hline $\begin{array}{l}\text { Antar bulan } \\
\text { Among months }\end{array}$ & 72,48 & 11 & 6,59 & 1,53 & $0,18 \mathrm{NS}$ \\
\hline $\begin{array}{l}\text { Error } \\
\text { Residual }\end{array}$ & 103,05 & 24 & 4,29 & & \\
\hline Total & 175,53 & 35 & & & \\
\hline
\end{tabular}

Keterangan: NS = tidak berbeda nyata pada taraf $5 \%$

Remark: $\quad$ NS $=$ not significant different at $5 \%$ level

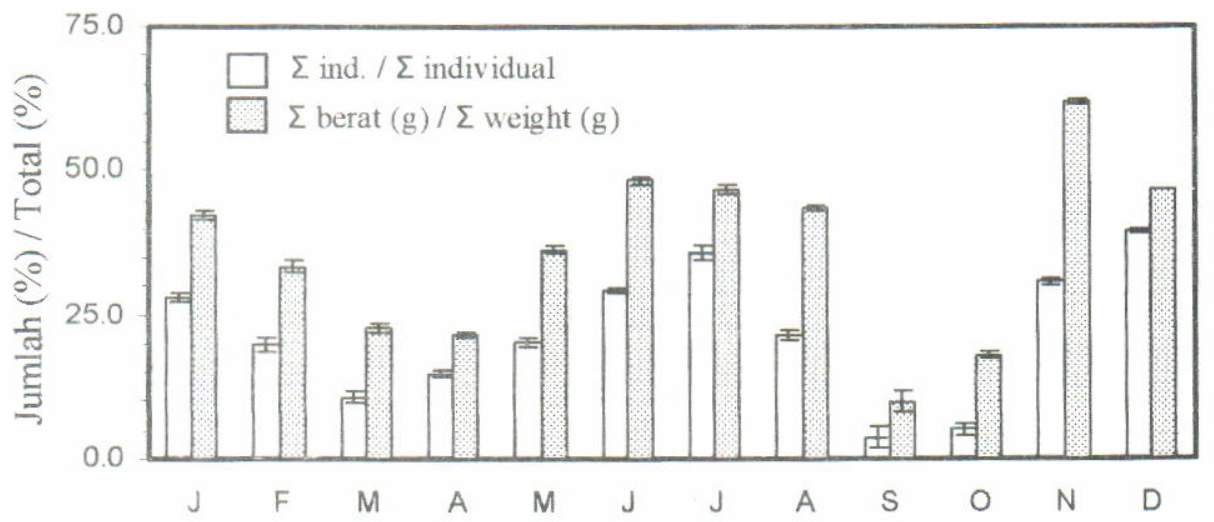

Gambar 2. Jumlah (\%) individu dan bobot ikan Engraulidae dibandingkan dengan total hasil tangkapan jaring pantai selama penelitian 1995 sampai dengan 1996 dan 2004.

Figure 2. Total (\%) individual and weight of Engarulids compared with the total samples during the study in 1995-1998 and 2004.

kemudian hasil regresi ini dianalisis (ANOVA) menunjukkan bahwa tidak berbeda nyata antar tahun pengamatan (Tabel 6). Berdasarkan pada ke-2 hasil ini, maka dikalkulasi regresi panjang bobot dengan menggunakan seluruh data (gabungan) untuk 4 jenis ini (Tabel 3), dan koefisien regresi (a dan b) ini yang dipergunakan untuk memprediksi $\mathrm{Kn}$.

Hasil ANOVA untuk perlakuan antar tahun disajikan pada Tabel 7, sedangkan antar bulan disajikan dalam grafik (Gambar 6). Dari 4 jenis yang dianalisis, hanya $S$. indicus yang memiliki variasi tahunan $\mathrm{Kn}$, sedangkan untuk variasi bulanan terlihat memiliki kecenderungan yang hampir sama khususnya bagi $E$. heteroloba dan S. indicus (memiliki contoh yang sepanjang tahun), yaitu menurun pada bulan Mei dan Juni, kemudian meningkat pada bulan September sampai dengan Nopember dan menurun kembali pada bulan Desember sampai dengan Pebruari, selanjutnya meningkat pada bulan Maret sampai dengan April. Hal ini, mengindikasikan adanya pengaruh yang sama dari faktor lingkungan atau musim terhadap kondisi biologi dari yang terjadi seperti periode pemijahan.

\section{BAHASAN}

\section{Sumber Daya Perikanan}

Ikan Engraulidae di Teluk Ambon sudah merupakan kelompok fauna ikan yang bernilai komersil sejak tahun 1970-an (Sumadhiharga, 1978; 1984; Wouthuyzen et al., 1984; Hutomo et al., 1987), dan sampai saat ini juga tetap memiliki nilai yang berarti dalam perikanan cakalang. Keberadaannya di Teluk Ambon tercatat hanya 7 jenis, yang berarti lebih 25\% dari keseluruhan jumlah jenis Engarulidae di Indonesia, sedangkan 4 dari 7 genusnya yang berada di perairan Indonesia ditemukan di Teluk Ambon, ini 
Tabel 3. Informasi selang panjang total 4 jenis Engraulidae, dan nilai ketetapan ( $a$ dan $b$ ) regresi panjang bobot

Table 3. Information on length ranges of 4 engraulid species, and constant ( $a$ and $b$ ) of length weight relatioship

\begin{tabular}{|c|c|c|c|c|c|c|c|}
\hline \multirow[t]{2}{*}{ No. } & \multirow[t]{2}{*}{$\begin{array}{l}\text { Jenis } \\
\text { Species }\end{array}$} & \multirow[t]{2}{*}{$\begin{array}{l}\text { Tahun } \\
\text { Year }\end{array}$} & \multirow[t]{2}{*}{$\begin{array}{l}\text { Iind } \\
\text { Zndv. }\end{array}$} & \multirow[t]{2}{*}{$\begin{array}{c}\text { Selang PT (cm) } \\
\text { Range of } \\
\text { total length }(\mathrm{cm})\end{array}$} & \multicolumn{2}{|c|}{$\begin{array}{c}\text { Konstanta } \\
\text { Constant }\end{array}$} & \multirow[t]{2}{*}{$\mathrm{R}^{2}$} \\
\hline & & & & & $\mathbf{a}$ & b & \\
\hline \multirow[t]{6}{*}{1.} & \multirow[t]{6}{*}{ E. heteroloba } & 1995 & 609 & $3,9-8,5$ & $610^{-3}$ & 3,0 & 0,9 \\
\hline & & 1996 & 653 & $4,1-11,0$ & $110^{-3}$ & 3,8 & 0,9 \\
\hline & & 1997 & 985 & $3,0-10,4$ & $210^{-3}$ & 3,5 & 0,9 \\
\hline & & 1998 & 368 & $3,9-9,6$ & $410^{-3}$ & 3,2 & 0,9 \\
\hline & & 2004 & 125 & $4,5-9,1$ & $1110^{-3}$ & 2,8 & 0,9 \\
\hline & & $\begin{array}{l}\text { Gabungan } \\
\text { Combined }\end{array}$ & 2.740 & $3,0-11,0$ & $210^{-3}$ & 3,5 & 0,9 \\
\hline \multirow[t]{2}{*}{2.} & \multirow[t]{2}{*}{ E. punctifer } & $\begin{array}{r}1995 \\
1996\end{array}$ & $\begin{array}{l}361 \\
350\end{array}$ & $\begin{array}{l}5,3-9,0 \\
6,7-9,3\end{array}$ & $\begin{array}{l}410^{-3} \\
210^{-3}\end{array}$ & $\begin{array}{l}3,3 \\
3,4\end{array}$ & $\begin{array}{l}0,8 \\
0,5\end{array}$ \\
\hline & & $\begin{array}{l}\text { Gabungan } \\
\text { Combined }\end{array}$ & 711 & $3,5-9,3$ & $410^{-3}$ & 3,3 & 0,7 \\
\hline \multirow[t]{2}{*}{3.} & \multirow[t]{2}{*}{ S. indicus } & $\begin{array}{l}1995 \\
1996 \\
1997 \\
1998 \\
2004\end{array}$ & $\begin{array}{l}259 \\
733 \\
508 \\
172 \\
135\end{array}$ & $\begin{array}{c}2,9-6,8 \\
2,5-10,2 \\
2,8-14,1 \\
4,2-11,0 \\
3,0-9,3\end{array}$ & $\begin{array}{l}2710^{-3} \\
210^{-3} \\
210^{-3} \\
310^{-4} \\
4610^{-3}\end{array}$ & $\begin{array}{l}2,3 \\
3,7 \\
3,5 \\
4,4 \\
2,2\end{array}$ & $\begin{array}{l}0,7 \\
0,8 \\
1,0 \\
0,9 \\
0,7\end{array}$ \\
\hline & & $\begin{array}{l}\text { Gabungan } \\
\text { Combined }\end{array}$ & 1.806 & $2,5-14,1$ & $410^{-3}$ & 3,2 & 0,8 \\
\hline \multirow[t]{2}{*}{4.} & \multirow[t]{2}{*}{ T. baelama } & $\begin{array}{l}1995 \\
1996 \\
1997 \\
1998\end{array}$ & $\begin{array}{c}60 \\
279 \\
25 \\
15\end{array}$ & $\begin{array}{l}4,0-12,1 \\
3,9-12,3 \\
3,6-13,2 \\
4,7-12,5\end{array}$ & $\begin{array}{ll}5 & 10^{-3} \\
8 & 10^{-4} \\
3 & 10^{-3} \\
5 & 10^{-5}\end{array}$ & $\begin{array}{l}3,1 \\
3,9 \\
3,3 \\
5,0\end{array}$ & $\begin{array}{l}1,0 \\
0,9 \\
1,0 \\
1,0\end{array}$ \\
\hline & & $\begin{array}{l}\text { Gabungan } \\
\text { Combined }\end{array}$ & 379 & $3,6-14,1$ & $110^{-3}$ & 3,8 & 0,9 \\
\hline
\end{tabular}

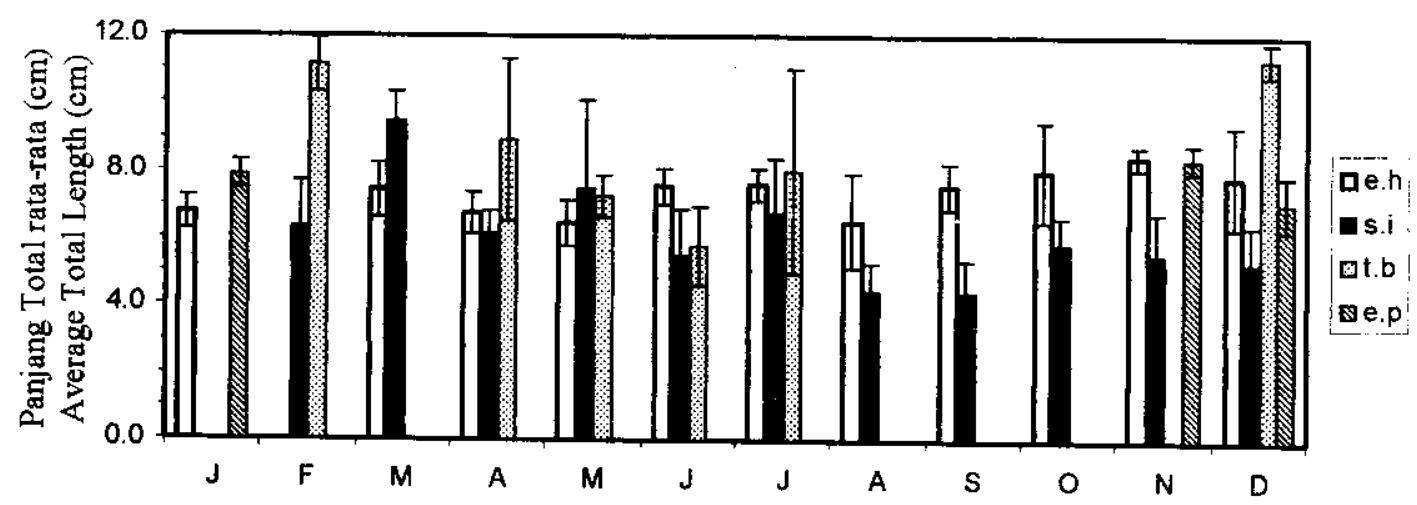

Gambar 3. Ukuran panjang total rata-rata setiap bulan dari 4 jenis Engaulidae (e.h=Encrasicholina heteroloba; $s . i=S t o l e p h o r u s$ indicus; t. $b=$ Trisinna baelama, and e. $\mathrm{p}=$ Encrasicolina puctifer) selama penelitian 1995 sampai dengan 1998 dan 2004.

Figure 3. Monthly average of total length for 4 Engraulids species (e. $\mathrm{h}=$ Encrasicholina heteroloba: $\mathrm{s.}$. $=$ Stolephorus indicus; t. $\mathrm{b}=$ Trisinna baelama, and e. $\mathrm{p}=$ =ncrasicolina puctifer) during study in 
Tabel 4. Ringkasan hasil Uji K-S untuk distribusi panjang tahunan dari 4 jenis Engraulidae di Teluk Ambon

Table 4. Results summary of K-S test for annual length average of 4 engarulids species caught in Ambon Bay

\begin{tabular}{|c|c|c|c|c|c|}
\hline & 1995 & 1996 & 1997 & 1998 & 2004 \\
\hline \multicolumn{6}{|l|}{ E. heteroloba } \\
\hline 1996 & $0,00^{* *}$ & - & & & \\
\hline 1997 & $0,00^{* *}$ & $0,00^{\star \star *}$ & - & & \\
\hline 1998 & $0,00^{* * *}$ & $0,00^{* *}$ & 0,00 ** & - & \\
\hline 2004 & $0,00^{* *}$ & $0,04^{*}$ & $0,00^{* *}$ & 0,00 ** & - \\
\hline \multicolumn{6}{|l|}{ S. indicus } \\
\hline 1996 & $0,00^{* * *}$ & - & & & \\
\hline 1997 & $0,00^{* *}$ & $0,00^{* *}$ & - & & \\
\hline 1998 & $0,00^{* *}$ & $0,00^{* *}$ & $0,00^{* *}$ & - & \\
\hline 2004 & $0,00^{* *}$ & $0,00^{* *}$ & $0,00^{* *}$ & 0,00 ** & - \\
\hline \multicolumn{6}{|l|}{ T. baelama } \\
\hline 1996 & $0,00^{\star * *}$ & - & & & \\
\hline 1997 & $0,00^{* *}$ & $0,00^{\star \star *}$ & - & & \\
\hline 1998 & $0,00^{\star *}$ & $0,01^{\text {**}}$ & $0,15 \mathrm{NS}$ & - & \\
\hline \multicolumn{6}{|l|}{ E. punctifer } \\
\hline 1996 & $0,00^{* *}$ & - & & & \\
\hline
\end{tabular}

Keterangan: * dan ${ }^{* *}=$ berbeda nyata pada taraf uji 5 dan $1 \%$, NS=tidak berbeda nyata pada taraf uji $5 \%$

Remark: "and ${ }^{* *}=$ significant different at $5 \%$ and $1 \%$ levels, NS $=$ not significant at $5 \%$ level

Tabel 5. Ringkasan hasil uji KS terhadap distribusi panjang antar bulan selama penelitian 1995 sampai dengan 1998 dan 2004 untuk 4 jenis Engarulidae

Table 5. Results summary of K-S test for monthly length average of 4 engarulids species caught in Ambon Bay

\begin{tabular}{|c|c|c|c|c|c|c|c|c|c|c|c|c|}
\hline & $J$ & $F$ & $M$ & A & $M$ & $\mathrm{~J}$ & $J$ & A & $\mathbf{S}$ & 0 & $\mathrm{~N}$ & D \\
\hline \multicolumn{13}{|c|}{ E. heteroloba } \\
\hline$J$ & - & & & & & & & & & & & \\
\hline $\mathrm{F}$ & n.d. & - & & & & & & & & & & \\
\hline M & $0,00^{\star \star}$ & n.d. & $0, \overline{-}^{\star \star \star}$ & & & & & & & & & \\
\hline A & $0,00^{\star \star}$ & n.d. & $\begin{array}{l}0,00^{\star \star} \\
0,00^{\star \star}\end{array}$ & $0,00^{* \star}$ & - & & & & & & & \\
\hline $\begin{array}{l}M \\
J\end{array}$ & $0,00^{* *}$ & $\begin{array}{l}\text { n.d. } \\
\text { n.d. }\end{array}$ & $0,00^{\star \star}$ & $0,00^{* *}$ & $0,00^{\star \star}$ & - & & & & & & \\
\hline J & $0,00^{\star \star}$ & n.d. & $0,00^{\star *}$ & $0,00^{\star \star}$ & $0,00^{\star \star}$ & $0,00^{* *}$ & _ & & & & & \\
\hline A & $0,00^{* *}$ & n.d. & $0,00^{* *}$ & $0,00^{\star \star}$ & $0,00^{\star \star}$ & $0,00^{\star *}$ & $0,00^{\star \star *}$ & - & & & & \\
\hline s & $0,00^{\star *}$ & n.d. & $0,10 \mathrm{NS}$ & $0,00^{* *}$ & $0,00^{\star \star}$ & $0,17 \mathrm{NS}$ & $0,25 \mathrm{NS}$ & $0,00^{\star \star}$ & - & & & \\
\hline 0 & $0,00^{\star *}$ & n.d. & $0,00^{\star \star}$ & $0,00^{* \star}$ & $0,00^{\star \star}$ & $0,00^{\star \star}$ & $0,00^{\star \star}$ & $0,00^{\star \star}$ & $0,00^{\star \star}$ & - & & \\
\hline $\mathrm{N}$ & $0,00^{\star \star}$ & n.d. & $0,00^{* *}$ & $0,00^{\star \star}$ & $0,00^{\star \star}$ & $0,00^{\star \star}$ & $0,00^{\star *}$ & $0,00^{\star \star}$ & $0,00^{\star \star}$ & $0,02^{*}$ & - & \\
\hline D & $0,00^{* \star}$ & n.d. & $0,00^{\star \star}$ & $0,00^{* *}$ & $0,00^{\star \star}$ & $0,00^{* \star}$ & $0,00^{\star *}$ & $0,00^{\star \star}$ & $0,00^{\star \star}$ & $0,08 \mathrm{NS}$ & $0,02^{*}$ & - \\
\hline \multicolumn{13}{|c|}{ S. indicus } \\
\hline $\mathrm{J}$ & - & & & & & & & & & & & \\
\hline $\mathrm{F}$ & t.d. & - & & & & & & & & & & \\
\hline M & t.d. & $0,00^{\star *}$ & - & & & & & & & & & \\
\hline A & t.d. & $0,00^{* *}$ & $0,00^{\star \star}$ & - & & & & & & & & \\
\hline M & t.d. & $0,00^{\star \star}$ & $0,00^{\star \star}$ & $0,00^{\star *}$ & - & & & & & & & \\
\hline $\mathrm{J}$ & t.d. & $0,00^{\star *}$ & $0,00^{\star *}$ & $0,00^{\star *}$ & $0,00^{\star *}$ & - & & & & & & \\
\hline$J$ & t.d. & $0,00^{\star \star}$ & $0,00^{\star \star}$ & $0,00^{\star *}$ & $0,00^{\star *}$ & $0,00^{\star \star}$ & - & & & & & \\
\hline A & t.d. & $0,00^{\star \star}$ & $0,00^{\star *}$ & $0,00^{\star *}$ & $0,00^{\star *}$ & $0,00^{\star \star}$ & $0,00^{\star *}$ & - & & & & \\
\hline $\mathrm{s}$ & t.d. & $0,00^{\star *}$ & $0,00^{\star \star}$ & $0,00^{\star \star}$ & $0,00^{\star *}$ & $0,00^{\star *}$ & $0,00^{\star \star *}$ & $0,76 \mathrm{NS}$ & - & & & \\
\hline 0 & t.d. & $0,00^{\star *}$ & $0,00^{\star *}$ & $0,00^{\star \star}$ & $0,00^{\star *}$ & $0,00^{\star \star \star}$ & $0,00^{\star * *}$ & $0,00^{\star \star}$ & $0,00^{\star *}$ & - & & \\
\hline $\mathrm{N}$ & t.d. & $0,00^{\star *}$ & $0,00^{\star \star *}$ & $0,00^{\text {** }}$ & $0,00^{\star *}$ & $0,30 \mathrm{NS}$ & $0,00^{\star \star \star}$ & $0,00^{\star *}$ & $0,00^{\star *}$ & $0,00^{\star \star}$ & - & \\
\hline D & t.d. & $0,00^{\star \star}$ & $0,00^{* *}$ & $0,00^{\star *}$ & $0,00^{\star *}$ & $0,23 N S$ & $0,00^{\star \star}$ & $0,00^{\star *}$ & $0,00^{* *}$ & $0,00^{\star \star}$ & $0,00^{\star \star}$ & \\
\hline
\end{tabular}


Tabel $5 \quad$ Lanjutan

$$
\begin{aligned}
& \text { T. baelama } \\
& \text { J } 0,0^{* \star} \\
& M \text { n.d. n.d. } \\
& \text { A } 0,00^{* *} \text { n.d } \\
& \text { M } 0,00^{* *} \quad 0,00^{* *} \\
& \text { J } 0,00^{* *} \quad 0,00^{* *} \\
& \text { J } 0,00^{\star \star} \quad \text { n.d. } \\
& \text { A n.d. n.d. } \\
& S \text { n.d. } \\
& \text { O n.d. } \\
& N \text { n.d. } \\
& \text { D } 0,00^{\star \star} \\
& \text { E. punctifer } \\
& \text { n.d } \\
& \text { n.d. } \\
& \text { n.d. } \\
& 0,00^{\star *} \\
& 0,00^{\star *} \quad 0,00^{\star \star} \\
& 0,26 N S \quad 0,05^{\star} \quad 0,06 N S \\
& \text { n.d. n.d. n.d. n.d. } \\
& \text { n.d. n.d. n.d. n.d. } \\
& \text { n.d. n.d. } \\
& \text { n.d. } \\
& \text { n.d. } \\
& \text { n.d. } \\
& \text { n.d. } \\
& \text { n.d. } \\
& \text { n.d. n.d. n.d. n.d. } \\
& \text { n.d. n.d. } \\
& 0,00^{\star *} \\
& 0,00^{\star *} \\
& 0,00^{\star *} \\
& 0,03^{\star} \\
& \text { n.d. } \\
& \text { n.d. } \\
& \text { n.d. } \\
& \text { n.d. } \\
& \text { n.d. n.d. } \\
& \text { n.d. } \\
& \text { n.d. } \\
& \text { n.d. - }
\end{aligned}
$$

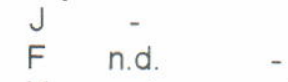

Tabel 6. Hasil ANOVA regresi panjang bobot dari 4 jenis Engraulidae untuk perlakuan perbedaan tahun pengambilan contoh ikan

Table 6. ANOVA results of length weight regression of 4 engraulid species, with annual sampling taken as treatment

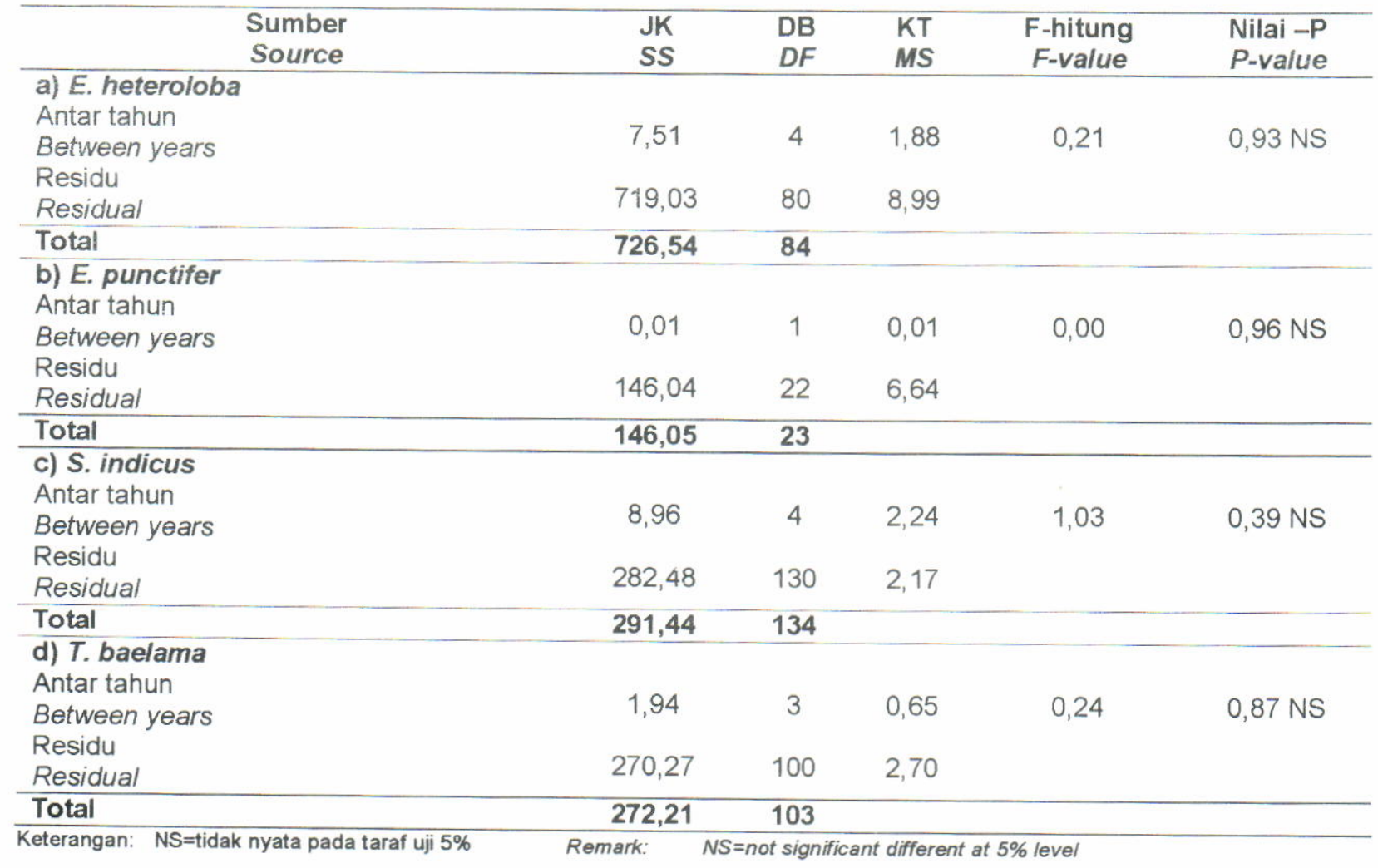




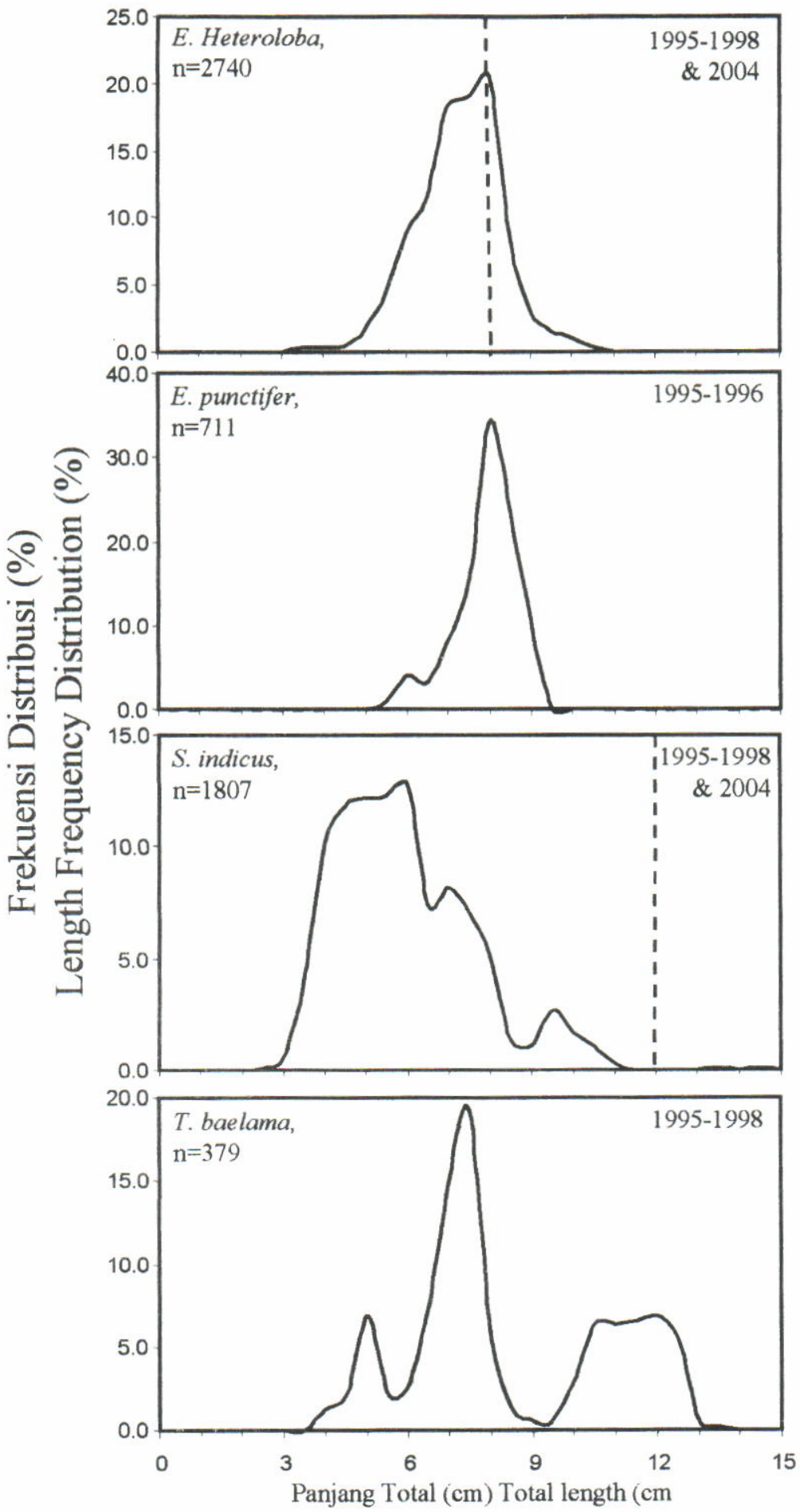

Gambar 4. Frekuensi distribusi (\%) panjang total 4 jenis Engarulidae, 1995 sampai dengan 1998 dan 2004. Keterangan: Garis putus-putus menandakan ukuran pertama kali matang gonada

Figure 4. Length frequency distribution (\%) of 4 Engarulids species, 1995-1998 and 2004

Remark: Dash line is marked first maturity length of the species 


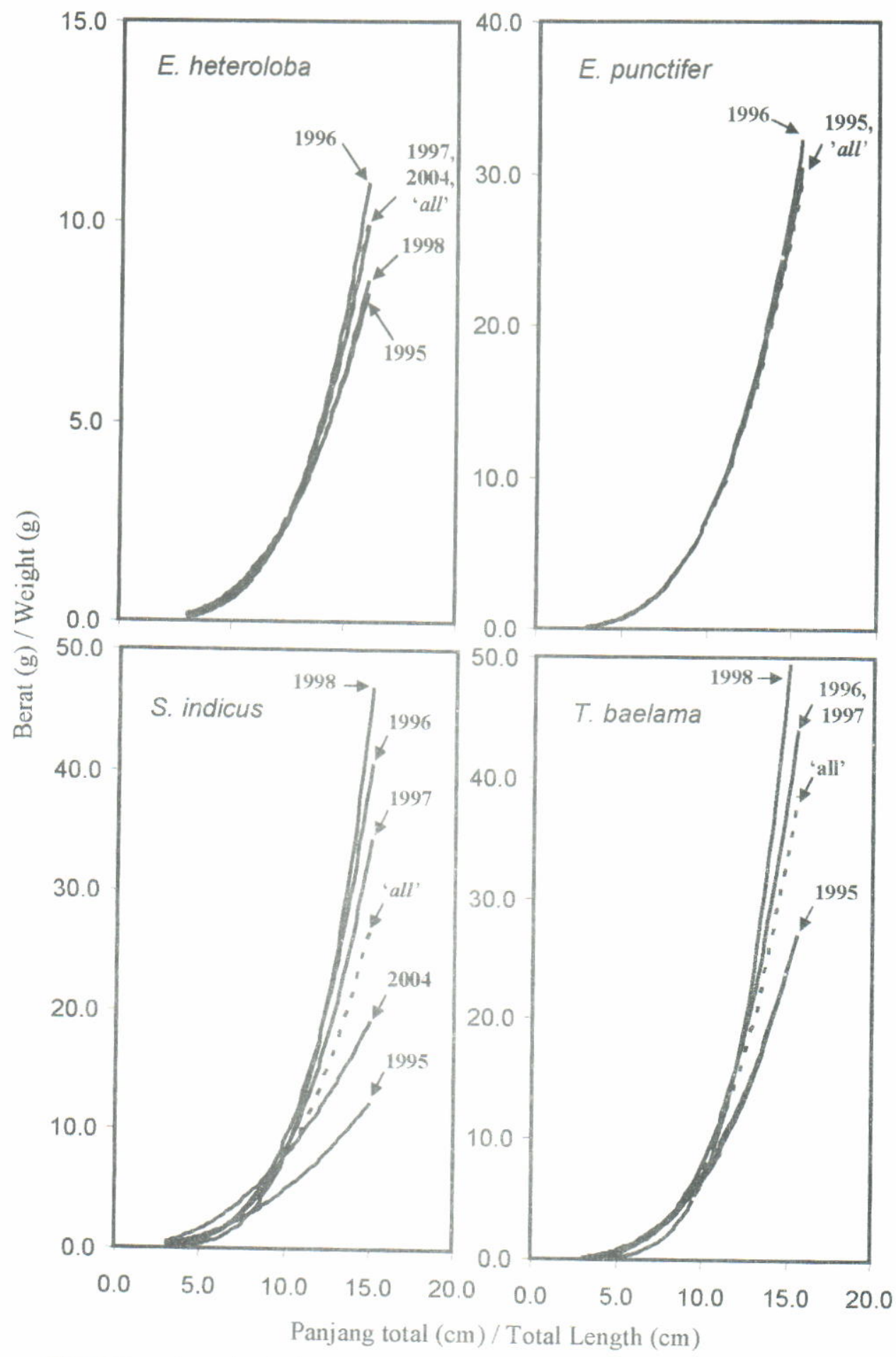
Gambar 5. Regresi panjang (cm) dan bobot $(\mathrm{g})$ dari 4 jenis Engraulidae, 1995 sampai dengan 1998 dan
2004 .

Figure 5 Keterangan: Garis putus-putus merupakan gabungan dari semua data

Regression of length and weight from 4 Engraulid species, 1995-1998, and 2004.

Remark: Dash line is combined samples 


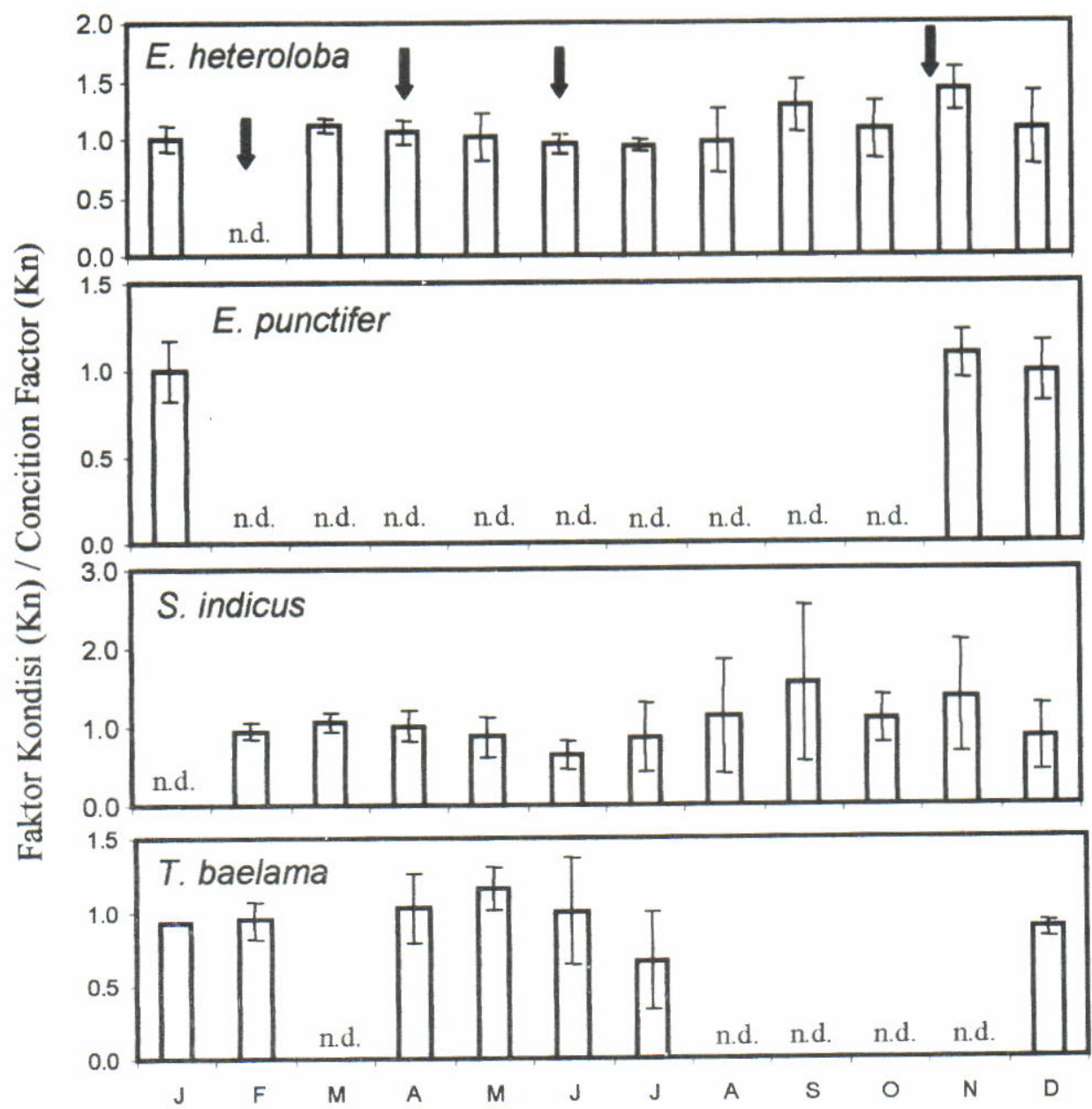

Gambar 6. Faktor kondisi (Kn) rata-rata setiap bulan dari 4 jenis Engraulidae, 1995 sampai dengan 1998 dan 2004

Keterangan: $n . d .=$ tidak ada contoh. Tanda panah menunjukkan puncak kelimpahan dari zooplankton di Teluk Ambon (Sutomo, 1989)

Figure 6. Monthly average of condition factor (Kn) of 4 Engraulids species, 1995-1998 and 2004. n.d=no samples available.

Remark: Arrows indicate the peak of zooplankton abundance in Ambon Bay (Sutomo, 1989)

sama dengan lebih dari $55 \%$. Hal ini wajar, karena lingkungan hidup dari ikan Engarulidae adalah daerah pesisir yang terlindung dan tenang, seperti Teluk Ambon.

Satu jenis hanya diidentifikasi pada tingkatan genus adalah Stolephorus sp., diperkirakan jenis ini kemungkinan Stolephorus sp. A atau S. devisi. Ke-2 jenis ini pernah ditemukan Sumadhiharga (1984) dan dalam penelitian ini jumlah individunya dan frekuensi kehadirannya juga sangat rendah, sehingga dianggap kurang memberikan dampak yang berarti dalam perikanan pelagis kecil.

Keberadaannya di Teluk Ambon hampir tanpa variasi yang berarti selama 10 tahun terakhir. Informasi ini sangat berarti, karena sejak periode tahun 1980-an kelimpahan ikan ini menurun secara drastis, sehingga diperkirakan telah terjadi masalah tangkap lebih (overfishing) dalam perikanan pelagis kecil. Kemungkinan kegagalan rekruitmen telah terjadi pada ikan Engraulidae di Teluk Ambon. Dari penelitian terdahulu, ditemukan bahwa ikan Engaulidae memijah di dalam Teluk Ambon (Troost et al., 1976), yaitu dengan ditemukannya telur ikan-ikan ini yang cukup melimpah. Sejalan dengan perubahan waktu yang juga berdampak pada perubahan lingkungan perairan di Teluk, maka kemungkinan proses pemijahan ini terjadi, tetapi lingkungannya tidak mendukung untuk ketahanan hidup larva dan juvenile. Akibatnya terjadi kegagalan rekruitmen yang selanjutnya menurunkan kelimpahan ikan Engraulidae.

\section{Strategi Pengelolaan}

Dari hasil penelitian ini dapat diungkapkan bahwa tidak semua jenis ikan-ikan Engaulidae ditangkap dalam ukuran yang belum dewasa atau belum pernah memijah. Dengan demikian, alat tangkap yang 
Tabel 7 Hasil ANOVA untuk $\mathrm{Kn}$ antar tahun bagi 4 jenis Engraulidae selama penelitian 1985 sampai dengan 1986 dan 2004

Table 7. ANOVA results for condition factors of 4 species engraulids in 1995-1998 and 2004

\begin{tabular}{|c|c|c|c|c|c|}
\hline $\begin{array}{c}\text { Sumber } \\
\text { Source }\end{array}$ & $\begin{array}{l}\text { JK } \\
\text { SS }\end{array}$ & $\begin{array}{l}\mathrm{DB} \\
\mathrm{DF}\end{array}$ & $\begin{array}{l}\text { KT } \\
\text { MS }\end{array}$ & $\begin{array}{l}\text { F-hitung } \\
\text { F-value }\end{array}$ & $\begin{array}{l}\text { Nilai P } \\
P \text {-value }\end{array}$ \\
\hline \multicolumn{6}{|l|}{$\begin{array}{l}\text { E. heteroloba } \\
\text { Antar tahun }\end{array}$} \\
\hline $\begin{array}{l}\text { Antar tahun } \\
\text { Between months }\end{array}$ & 0,17 & 4 & 0,04 & 1,53 & $0,19 \mathrm{NS}$ \\
\hline $\begin{array}{l}\text { Residu } \\
\text { Residual }\end{array}$ & 77,76 & 2735 & 0,03 & & \\
\hline Total & 77,93 & 2739 & & & \\
\hline \multicolumn{6}{|l|}{$\begin{array}{l}\text { E. punctifer } \\
\text { Antar tahun }\end{array}$} \\
\hline $\begin{array}{l}\text { Antar tahun } \\
\text { Between months } \\
\text { Residu }\end{array}$ & 0,00 & 1 & 0,00 & 0,03 & $0,86 \mathrm{NS}$ \\
\hline $\begin{array}{l}\text { Residu } \\
\text { Residual }\end{array}$ & 21,02 & 709 & 0,03 & & \\
\hline Total & 21,02 & 710 & & & \\
\hline \multicolumn{6}{|l|}{$\begin{array}{l}\text { S. indicus } \\
\text { Antar tahun }\end{array}$} \\
\hline $\begin{array}{l}\text { Between months } \\
\text { Residu }\end{array}$ & 1,98 & 4 & 0,49 & 2,89 & $0,02^{* *}$ \\
\hline Residual & 308,18 & 1802 & 0,17 & & \\
\hline Total & 310,16 & 1806 & & & \\
\hline \multicolumn{6}{|l|}{$\begin{array}{l}\text { T. baelama } \\
\text { Antar tahun }\end{array}$} \\
\hline $\begin{array}{l}\text { Between months } \\
\text { Residu }\end{array}$ & 0,07 & 3 & 0,02 & 0,45 & $0,72 \mathrm{NS}$ \\
\hline Residual & 18,66 & 375 & 0,05 & & \\
\hline Total & 18,72 & 378 & & & \\
\hline
\end{tabular}

dioperasikan memiliki ukuran mata jaring yang belum dapat meloloskan ikan-ikan muda dari kelompok ikan Engaraulidae secara lebih baik. Untuk itu, diperlukan suatu peraturan tentang pengaturan mata jaring yang ideal bagi perikanan pelagis kecil di Teluk Ambon.

Secara alamiah, lingkungan perairan Teluk Ambon dapat mendukung sumber daya perikanan pelagis kecil (Syahailatua, 1999), tetapi khusus untuk ikan Engraulidae kemungkinan tidak demikian, karena jumlah produksi yang terus menurun sejak tahun 1980-an. Dengan demikian, diperlukan suatu tindakan pengendalian masukkan limbah yang berlebihan dari daratan, supaya kualitas perairan tetap dipertahankan (a.l. Wouthuyzen, 2001).

Beberapa studi terdahulu sudah dapat mengungkapkan kondisi pemijahan ikan Engraulidae (a.I. Sumadhiharga, 1978; 1984; 1989), yaitu memijah beberapa kali dalam 1 musim pemijahan, dan puncak pemijahan terjadi antara bulan Agustus sampai dengan Nopember. Di samping itu, hasil studi plankton juga mengungkapkan adanya telur dan larva ikannya di Teluk Ambon bagian dalam (Troost et al., 1976) yang terjadi sepanjang tahun. Berdasarkan pada informasi ini, maka dapat dipertimbangkan untuk melakukan pengurangan aktivitas penangkapan atau bahkan penutupan musim penangkapan antara bulan
Agustus sampai dengan Nopember. Upaya ini dilakukan, supaya telur, larva dan ikan-ikan muda dari kelompok ikan Engraulidae dapat diberi kesempatan berkembang secara baik dan mengalami rekruitmen. Selama ini secara alamiah, nelayan melakukan pengurangan aktivitas melaut pada saat musim timur di mana curah hujan agak tinggi. Hal ini, perlu ditindaklanjuti, sehingga penurunan produksi perikanan ikan umpan dapat ditingkatkan.

\section{UCAPAN TERIMA KASIH}

Kegiatan penelitian ini pada awalnya didanai oleh APBN 1995/1996. Penulis mengucapkan terima kasih kepada La Pay, Yance Hehuat, Dominggus Bremen, dan James Latuheru yang sudah membantu selama pengumupulan contoh ikan dan analisis di laboratorium. Ucapan terima kasih juga disampaikan kepada reviewers yang telah memberikan saran untuk perbaikan naskah tulisan ini.

\section{DAFTAR PUSTAKA}

Anderson, J. J. \& D. Sapulete. 1981. Deep water renewal in inner Ambon Bay, Ambon, Indonesia. Proceeding of the 4th International Coral Reef Symposium, Manila. Vol.1. 
Cone, R. S. 1989. The need to reconsider the use of condition indices in fishery science. Trans. Am. Fish. Soc. 118:510-514.

Froese, R. \& D. Pauly (ed.). 2005. Fish base world wide web electronic publication. $\mathrm{mw}$. fishbase.org, version (02/2005)

Hermanto, B. 1987. Analisa morfologi pantai teluk Ambon. Dalam Soemodihardjo, S., Birowo, S., \& Romimohtarto, K. (eds) Teluk Ambon; Biologi, Perikanan, Oseanografi, dan Geologi. Balai Penelitian dan Pengembangan Sumber Daya Laut. Pusat Penelitian dan Pengembangan Oseanologi. Lembaga IImu Pengetahuan Indonesia. Ambon: 145-152.

Hutahaean, W. 1996. Characteristics of subsurface temperatures and currents in Ambon Inner Bay. Perairan Maluku dan Sekitarnya. 11:131-138.

Hutomo, M., Burhanuddin, Djamali A., \& Martosewojo S. 1987. Sumber daya ikan teri di Indonesia. Seri: Sumber Daya Alam 137. Pusat Penelitian dan Pengembangan Oseanologi. Lembaga IImu Pengetahuan Indonesia. Jakarta. 80 pp.

Pattikawa, J. A. \& Ongkers O. T. S. 2002. Dinamika populasi ikan puri putih (Stolephorus indicus) di Teluk Ambon bagian dalam. J. Ichthyos, 1 (1): 4247

Sokal, R. R. \& Rohlf F. J. 1969. Biometry: the principles and practice of statistics in biological reserach. W. H. Freeman \& Company, San Francisco: 776 pp

Steel, R. G. D. \& Torrie J. H. 1993. Prinsip dan prosedur statistika: suatu pendekatan biometrik. Gramedia Pustaka Utama. Jakarta: 772 pp.

Sumadhiharga, O. K. 1978. Beberapa aspek biologi ikan puri (teri), Stolephorus heterolobus (Ruppel), di Teluk Ambon. Oseanologi di Indonesia, 9: 2941.

Sumadhiharga, O. K. 1984. Some reproductive biology of three species of anchovies (Stolephorus) from Ambon Bay, Indonesia. MSc Thesis. University of Washington, USA. 86 pp.

Sumadhiharga, O. K. 1989. Biologi reproduksi tiga jenis ikan teri (Stolephorus) dari Teluk Ambon. Dalam Soemodihardjo, S., Birowo, S., \& Romimohtarto, K. (eds) Teluk Ambon: Biologi, Perikanan, Oseanografi, dan Geologi. Balai Penelitian dan Pengembangan Sumber Daya Laut. Pusat Penelitian dan Pengembangan Oseanologi. Lembaga IImu Pengetahuan Indonesia. Ambon: 67-74.
Sumadhiharga, O. K. \& Yulianto, K. 1987. Pengamatan beberapa aspek biologi dan masalah yang dihadapi perikanan ikan umpan di Teluk Ambon. Dalam Soemodihardjo, S., Birowo, S., \& Romimohtarto, K. (eds.). Teluk Ambon: Biologi, Perikanan, Oseanografi, dan Geologi. Balai Penelitian dan Pengembangan Sumber Daya Laut. Pusat Penelitian dan Pengembangan Oseanologi. Lembaga IImu Pengetahuan Indonesia. Ambon: 55-61.

Sutomo \& Anderson, J. J. 1984. Phytoplankton and zooplankton abundance in Ambon Bay. Mar. Res. Indonesia, 23: 1-11.

Syahailatua, A. 1998. Struktur komunitas ikan-ikan hasil tangkapan jaring pantai di Lateri, Teluk Ambon: Suatu Studi Pendahuluan. Dalam Wenno, L. F., Noor, A., Dwiono, S. A. P., Syamsuddin, R., \& Wiadnyana, N. N. (eds.). Prosiding Seminar Kelautan, Lembaga IImu Pengetahuan Indonesia, Universitas Hasanuddin ke-1, Ambon 4-6 Juli 1997. Balai Penelitian dan Pengembangan Sumber Daya Laut. Lembaga IImu Pengetahuan Indonesia. Ambon: 107-115.

Syahailatua, A. 1999. Komunitas fauna ikan yang tertangkap dengan jaring pantai dan bagan apung di Teluk Ambon dalam, 1995-1997. Oseanologi dan Limnologi di Indonesia, 31: 41-55.

Tarigan, M. S. \& Sapulete D. 1987. Perubahan musiman suhu air laut di Teluk Ambon bagian dalam. Dalam Soemodihardjo, S., Birowo, S., \& Romimohtarto, K. (eds) Teluk Ambon; Biologi, Perikanan, Oseanografi, dan Geologi. Balai Penelitian dan Pengembangan Sumber Daya Laut. Pusat Penelitian dan Pengembangan Oseanologi. Lembaga IImu Pengetahuan Indonesia. Ambon: 81-90.

Troost, D. G., Sutomo A. B., \& Wenno L. F. 1976. Distribution and abundance of major zooplankton groups in Ambon Bay (Maluku, Indonesia) during a salp swarming, with notes on Chaetognatha and Pteropoda Species. Mar. Res. Indonesia, 16: 2944.

Walman \& Anderson J. J. 1987. Currents and mixing on the sill of Ambon Bay measured with drogues. Mar. Res. Indonesia, 26: 1-11.

Wenno, L. F. 1986. Beberapa keunikan Teluk Ambon dalam. Lonawarta, ThX (4): 1-6.

Wenno, L. F. 1979. Pola sebaran suhu air di Teluk Ambon. Oseanologi di Indonesia, 12: 21-29.

Wenno, L. F. 1997. Kondisi oseanografi fisika dan kepadatan biomassa Teluk Ambon. Dalam Wenno, 
L. F., Noor, A., Dwiono, S. A. P., Syamsuddin, R., \& Wiadnyana, N. N. (eds.). Prosiding Seminar Kelautan Lembaga IImu Pengetahuan Indonesia, Universitas Hasanuddin ke-1, Ambon 4-6 Juli 1997. Balai Penelitian dan Pengembangan Sumber Daya Laut Lembaga IImu Pengetahuan Indonesia. Ambon: 7-28.

Wenno, L. F. \& J. J. Anderson. 1984. Evidence for tidal upwelling across the sill of Ambon Bay. Mar. Res. Indonesia, 23: 13-20.

Whitehead, P. J. P. 1985. FAO species catalogue. Vol.7. Clupeoid Fishes of The World (Suborder Clupeoidei). An Annotated and Illustrated
Catalogue of The Herrings, Sadrines, Pilchards, Sprats, Anchovies, and Wolf-Herrings. Part 1, Chirocentridae, Clupeidae, and Pristigasteridae. FAO Fish. Synop. (125) Vol.7, Pt. 1: 303 pp.

Wouthuyzen, S. 2001. Sifat optic Teluk Ambon dan kaitannya dengan masalah lingkungan. Oseanologi dan Limnologi di Indonesia, 33: 15-26.

Wouthuyzen, S. A. Suwartana, \& O. K. Sumadhiharga. 1984. Studi tentang dinamika populasi ikan puri merah, Stolephorus Heterolobus (Rüppell) dan kaitannya dengan perikanan umpan di Teluk Ambon bagian dalam. Oseanologi di Indonesia, 18: 1-20. 